\title{
Heifer Body Weight Gain and Reproductive Achievement in Response to Protein and Energy Supplementation While Grazing Dormant Range Forage
}

\author{
Richard C. Waterman1,2*, Jason E. Sawyer ${ }^{3}$, Kim K. Kane4, Dean E. Hawkins', \\ Mark K. Petersen² \\ ${ }^{1}$ Department of Animal and Range Sciences, New Mexico State University, Las Cruces, USA \\ ${ }^{2}$ USDA-ARS, Fort Keogh LARRL, Miles City, USA \\ ${ }^{3}$ Department of Animal Science, Texas A\&M University, College Station, USA \\ ${ }^{4}$ Gift of Goodbye, In-Home Pet Hospice, Mesilla Park, USA \\ ${ }^{5}$ Department of Agricultural Sciences, West Texas A\&M, Canyon, USA \\ Email: ${ }^{*}$ richard.waterman@ars.usda.gov
}

Received 27 September 2014; revised 26 October 2014; accepted 10 November 2014

Copyright (C) 2014 by authors and Scientific Research Publishing Inc.

This work is licensed under the Creative Commons Attribution International License (CC BY). http://creativecommons.org/licenses/by/4.0/

(c) () D Den Access

\begin{abstract}
Heifers grazing winter range require supplemental nutrients to complement dormant forage to achieve optimal growth and performance. A study was conducted to evaluate nutritional environment and effect of different supplementation strategies for developing heifers grazing dormant winter range. Eighty-four Angus crossbred heifers were stratified by body weight at weaning, allocated to one of six replicated pastures, and randomly assigned one of three supplemental treatments: 1) $908 \mathrm{~g} / \mathrm{d}$ of a control supplement providing $340 \mathrm{~g} \cdot \mathrm{hd}^{-1} \cdot \mathrm{d}^{-1} \mathrm{of} \mathrm{CP}$ with $130 \mathrm{~g}$ of rumen undegradable protein (RUP) and 614 MJ of ME (LRUP); 2) $908 \mathrm{~g} / \mathrm{d}$ of a RUP supplement providing

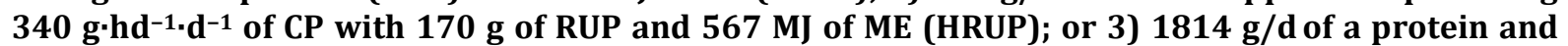
energy supplement providing $340 \mathrm{~g} \cdot \mathrm{hd}^{-1} \cdot \mathrm{d}^{-1}$ of CP with $120 \mathrm{~g}$ of RUP $+100 \mathrm{~g}$ of propionate salt (NutroCal' ${ }^{\mathrm{m}}$, Kemin Industries, Inc.) and 1222 MJ of ME (LRUP + E). Body weights were taken in November, with monthly $12 \mathrm{~h}$ shrunk BW from January thru April, and again in September (at time of pregnancy diagnosis). Heifer average daily gain was similar throughout the developmental period except from d125 to d159 where LRUP + E supplemented heifers had greater gains $(P<0.01)$ than LRUP and HRUP supplemented heifers $(0.33,0.04$, and $0.14 \pm 0.05 \mathrm{~kg} / \mathrm{d}$, respectively). LRUP + E heifers had a greater percentage $(P=\mathbf{0 . 0 4})$ of heifers pubertal at time of artificial insemination compared to LRUP and HRUP heifers $(57,29$, and 30, respectively). However, no differences were
\end{abstract}

\footnotetext{
${ }^{*}$ Corresponding author.
}

How to cite this paper: Waterman, R.C., Sawyer, J.E., Kane, K.K., Hawkins, D.E. and Petersen, M.K. (2014) Heifer Body Weight Gain and Reproductive Achievement in Response to Protein and Energy Supplementation While Grazing Dormant Range Forage. Agricultural Sciences, 5, 1296-1304. http://dx.doi.org/10.4236/as.2014.513138 
detected in overall pregnancy rates $(P=0.40)$. This study indicated that feeding more supplemental energy (i.e., propionate salt, ground milo and corn) allowed lightweight heifers to achieve a greater rate of gain at a key period during development and achieved comparable reproductive success to heifers only receiving supplemental protein.

\section{Keywords}

\section{Beef Heifers, Grazing, Energy Supplementation, Protein Supplementation}

\section{Introduction}

Development of replacement females to calve as a 2-yr-old while grazing dormant native range in a semi-arid environment is challenging since grazeable forage may supply an inadequate amount of dietary nutrients. Therefore, supplementation strategies that complement dormant forage to optimize growth and reproductive performance of range raised heifers may be advantageous. In addition, variability in climate influences forage availability and nutrient denseness in semi-arid regions. Inadequate precipitation during critical times of the year (i.e. forage growing season) can impact relative forage quality and quantity. Furthermore, lack of nutrient adequate forages can limit growth rate and development of heifers. To achieve development goals producers can implement supplementation strategies to supply additional nutrients to offset nutrient inadequacies originating from senescent forages.

Heifers receiving no supplemental nutrients when grazing dormant forage have been shown to maintain or lose (average daily gain (ADG) ${ }^{1}-0.03 \mathrm{~kg} / \mathrm{d}$ ) body weight [1]. Dormant forages tend to be inadequate in crude protein (CP) and therefore, cannot meet CP requirements [2] for growing cattle [3]-[5], resulting in limited ruminal function, microbial protein turn-over, and supply of glucogenic precursors such as propionate and glucogenic amino acids [6].

Management strategies often require heifers to not only achieve puberty but conceive by 15 months of age, so that they can calve at 2 years of age [7]. Heifers attaining puberty and conceiving earlier tend to wean heavier calves than heifers conceiving later in the breeding season. Furthermore, heifers that conceive earlier in the breeding season greatly improve their ability to be sustained within the herd [7] [8]. The primary factors influencing puberty include nutrition and breed type [8] [9].

Ruminal manipulation of acetate:propionate ratios by means of concentrate feeds [10] or monensin significantly reduces age when puberty occurs in heifers [10]-[13]. Heifers gaining BW at different rates during the prepuberal period but achieving similar body weights prior to the breeding season have been shown to achieve puberty at the same age [14]. Identification of nutrient limitations that may occur when dormant forages are grazed allows strategic supplementation strategies to be designed with respect to the dynamic nature of the environment. These supplementation strategies could target specific nutrient limitations and enhance efficiencies in heifers by decreasing days to puberty.

Supplementation with rumen undegradable protein (RUP) can improve feed intake, ADG, feed conversion, and provide glucogenic precursors to improve glucose status [6]. Other feed additives have been used to enhance production of glucose by altering ruminal volatile fatty acid (VFA) production using ionophores [15] [16]. When glucose limits metabolic function, propionate salts can be directly fed to supply propionate for gluconeogenesis to potentially enhance weight gain, and nutritional status [17]. Our objectives were to monitor body weight change, nutritional status, attainment of puberty, and conception rates for heifers grazing native winter range in response to protein supplements varying in ruminally degradable protein (RDP) to RUP ratios. A secondary objective was to determine if lighter weight heifers have improved body weight change when provided an isonitrogenous supplement providing additional MJ of energy partially supplied by propionate salt.

\section{Materials and Methods}

Animal care and management practices were in accordance with New Mexico State University Institutional

${ }^{1}$ Abbreviations used: ADG, average daily gain; CP, crude protein; RUP, rumen undegradable protein; VFA, volatile fatty acid; RDP, ruminally degradable protein; NDF, neutral detergent fiber; BW, body weight; SUN, serum urea N. 
Animal Care and Use Committee guidelines. Heifers were allowed free access to well water and loose trace mineralized salt fed in wind-protected feeders.

\subsection{Animals, Environment, and Treatments}

Experiments conducted during the winter and spring at the Corona Range and Livestock Research Center, which is located $300 \mathrm{~km}$ northeast of Las Cruces, NM, USA, and $13 \mathrm{~km}$ northeast of Corona, NM, USA (34 '14'58" latitude and $-105^{\circ} 35^{\prime} 48^{\prime \prime}$ longitude). Average elevation is 2,000 $\mathrm{m}$ with an average annual precipitation of 380 $\mathrm{mm}$, with the majority of precipitation occurring in late summer between July and August. Pastures utilized in this study were part of an ongoing study evaluating effects of tebuthiuron on control of encroaching woody vegetation. These pastures consisted of three pastures of 105 ha that received no tebuthiuron and three pastures of 77 ha which were treated with tebuthiuron. All six pastures had been lightly grazed during the previous winter. Vegetation was composed of a major overstory of moderate to dense woodlands consisting of Pinyon pine (Pinus edulis) and various juniper species (Juniperus spp). Predominant grasses in these pastures included; blue grama (Bouteloua gracilis), sideoats grama (B. curtipendula), hairy grama (B. hirsuta), sand dropseed (Sporobolus cryptandrus), wolftail (Lycurus phleoides), threeawns (Aristida spp), and black grama (Bouteloua eriopo$d a$ ) with minor components of other grasses and annual forbs [18] [19]. The average annual forage production in the study pastures are 560 and $1150 \mathrm{~kg} / \mathrm{ha}$ for no tebuthiuron treated and tebuthiuron treated, respectively (G. B. Donart, New Mexico State University, unpublished data).

Diet extrusa samples were collected in February and April using ruminally cannulated heifers to describe the nutritional composition of the dormant winter range forages grazed by supplemented heifers. Ruminal contents from cannulated heifers were completely removed and stored in $208 \mathrm{~L}$ plastic tubs, and ruminal walls were sponge dried to remove any residual moisture from the rumen as described by Lesperance et al. [20]. After removal of ruminal contents, heifers were released into experimental pastures and allowed to graze for 45 to 60 min. After the grazing period, an aliquot of extrusa was collected from each cannulated heifer and original ruminal contents were replaced. Collected extrusa samples (one for each heifer) were placed into a forced-air oven at $55^{\circ} \mathrm{C}$ for 48 to $72 \mathrm{~h}$ with continual turning every $6 \mathrm{~h}$ until extrusa samples were free of moisture. Following drying, extrusa samples were ground through a Wiley mill (2 mm screen), and analyzed for CP using the micro-Kjeldahl protocol [21] and neutral detergent fiber (NDF) [22]. Organic matter was determined by ashing ground extrusa samples in a muffle furnace at $600^{\circ} \mathrm{C}$ for $6 \mathrm{~h}$ (Table 1).

Eighty four predominantly Angus heifers with minor proportions of Hereford and Simmental breeding were stratified by body weight (BW) at weaning into 2 weight treatments. One weight treatment was composed of 55 heifers with a BW of $230 \pm 2.0 \mathrm{~kg}$ and a lighter BW group made up of 29 heifers with a mean weight of $206 \pm$ $2.6 \mathrm{~kg}$. The heavier BW heifers were allocated to one of four replicated paddocks, and randomly assigned to one of two supplementation treatments. Treatments consisted of a low-input strategy utilizing either $908 \mathrm{~g} / \mathrm{d}$ of a supplement containing $327 \mathrm{~g} \cdot \mathrm{hd}^{-1} \cdot \mathrm{d}^{-1}$ of CP with $125 \mathrm{~g}$ of RUP and $614 \mathrm{MJ}$ of ME (LRUP; $\mathrm{n}=28$ ), or $908 \mathrm{~g} / \mathrm{d}$ of a supplement containing $329 \mathrm{~g} \cdot \mathrm{hd}^{-1} \cdot \mathrm{d}^{-1}$ of CP with $163 \mathrm{~g}$ of RUP and 567 MJ of ME (HRUP; $\mathrm{n}=27$; Table 2). Then, twenty-nine heifers weighing approximately $24 \mathrm{~kg}$ less than the heavier BW treatment were allocated to one of two replicated paddocks, and supplemented with a greater nutritional input management plan providing

Table 1. Composition of dormant range forage collected by ruminally cannulated heifers in February and April.

\begin{tabular}{|c|c|c|}
\hline \multirow[t]{2}{*}{ Nutrient } & \multicolumn{2}{|c|}{ Extrusa Samples of Dormant Native Range ${ }^{a}$} \\
\hline & February & April \\
\hline Dry Matter, \% & 93.1 & 93.2 \\
\hline Organic Matter, \% & 86.1 & 82.3 \\
\hline Neutral Detergent Fiber & 80.7 & 79.4 \\
\hline Crude Protein & 5.2 & 7.7 \\
\hline
\end{tabular}

${ }^{\mathrm{a}}$ Predominant grasses included: blue grama (Bouteloua gracilis), sideoats grama (B. curtipendula), hairy grama (B. hirsuta), sand dropseed (Sporobolus cryptandrus), wolftail (Lycurus phleoides), threeawns (Aristida spp.), and black grama (Bouteloua eriopoda) with minor components of other grasses and annual forbs native to southwestern United States. 
Table 2. Ingredients and chemical composition of supplements fed to developing heifers on an as fed basis.

\begin{tabular}{|c|c|c|c|}
\hline \multirow[b]{2}{*}{ Item } & \multicolumn{3}{|c|}{ Supplements ${ }^{\mathrm{a}}$} \\
\hline & LRUP & HRUP & LRUP + E \\
\hline Ingredient composition & \multicolumn{3}{|c|}{ - } \\
\hline Cottonseed meal & 42.1 & 47.9 & 26.0 \\
\hline Milo, ground & 9.0 & 15.8 & 40.0 \\
\hline Molasses & 11.7 & 10.9 & 10.0 \\
\hline Urea & 1.2 & 0.7 & 0.7 \\
\hline Blood and Fish meal & 0.0 & 17.5 & 0.0 \\
\hline NutroCal $^{\mathrm{b}}$ & 0.0 & 0.0 & 5.4 \\
\hline Soybean meal, $47.5 \%$ & 30.0 & 0.0 & 0.0 \\
\hline Corn, ground & 0.0 & 0.0 & 13.8 \\
\hline Other & 6.0 & 7.2 & 4.1 \\
\hline \multicolumn{4}{|l|}{ Chemical Composition $^{\mathrm{c}}$} \\
\hline Amount, As fed & 908 & 908 & 1814 \\
\hline Energy, MJ & 614 & 567 & 1222 \\
\hline Crude Protein & 328 & 330 & 327 \\
\hline Rumen undegradable protein & 126 & 163 & 131 \\
\hline Rumen degradable protein & 202 & 166 & 197 \\
\hline Phosphorus & 6.6 & 6.9 & 10.9 \\
\hline
\end{tabular}

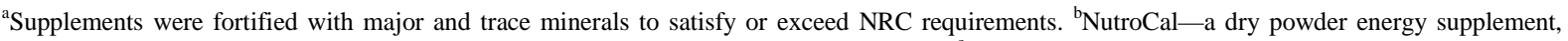
which contains $78.43 \%$ propionic acid, $21.36 \%$ calcium, $0.155 \%$ zinc and $0.053 \%$ copper. ${ }^{\circ}$ Calculated using the chemical composition of the dietary ingredients.

$1814 \mathrm{~g} / \mathrm{d}$ of an energy plus protein supplement. The protein content was similar to that found in LRUP consisting of $327 \mathrm{~g} \cdot \mathrm{hd}^{-1} \cdot \mathrm{d}^{-1}$ of CP with $130 \mathrm{~g}$ of RUP. This supplement also contained twice as much carbohydrate and $100 \mathrm{~g}$ of NutroCal $^{\mathrm{TM}}$ (78.43\% propionic acid, $21.36 \%$ calcium, $0.155 \%$ zinc and $0.053 \%$ copper on a DM basis Kemin Industries, Inc.) and 1222 MJ of ME (LRUP + E; $n=29$; Table 2). Lighter BW heifers assigned to the high-input group are usually not considered for replacements due to lighter BW and the expectation that they will not attain puberty by 15 months of age when developed on native range. This third treatment allowed the study to assess if lighter BW heifers supplemented with protein plus additional energy which included glucogenic precursors would compensate and achieve puberty at a similar age as LRUP and HRUP heifers receiving no additional caloric supplementation. Supplements were fed for $184 \mathrm{~d}$ from October through April. Replications of LRUP, HRUP, and LRUP + E feed treatments were used in a factorial arrangement across two woody vegetation management treatments in a companion study occurring simultaneously at the study site: aerial herbicide (to kill scrub vegetation) or no herbicide. Vegetation treatments did not interact with supplement strategy results; therefore, the vegetation management treatments were ignored. Protein supplements can be delivered less frequently due to recycling of nitrogen into the rumen whereas energy type supplements are less effective when fed at infrequent intervals [1]. Therefore, the LRUP and HRUP protein supplements were delivered twice a week and the LRUP + E was delivered three times a week with the purpose of providing protein and additional energy while attempting to optimize supplement effectiveness and costs associated with delivery. Supplementation ended $14 \mathrm{~d}$ prior to timed artificial insemination and immediate introduction to bulls.

At the termination of supplementation just prior to breeding two blood samples were collected $10 \mathrm{~d}$ apart via coccygeal venipuncture for determination of puberty (i.e., estrous activity). The occurrence of progesterone concentrations greater than one $\mathrm{ng} / \mathrm{mL}$ in both samples was used to establish that heifers were exhibiting estrous 
prior to synchronization. Progesterone was analyzed using solid phase RIA (Coat-A-Count; Diagnostic Products Corp., Los Angeles, CA) as validated by Schneider and Hallford [23] with an interassay coefficient of variation of $5.6 \%$ and $106 \%$ recovery. All heifers were synchronized using a norgestomet implant (Syncro-Mate $\mathrm{B}^{\mathrm{TM}}$; Merial, Atlanta, GA.). Implants were inserted into the left ear and removed $10 \mathrm{~d}$ later at which time a $5 \mathrm{ml}$ injection of prostaglandin (Lutalyse; Pharmacia \& Upjohn, Kalamazoo, MI) was administered. Artificial insemination occurred 48 to $54 \mathrm{~h}$ following removal of norgestomet implant. Following insemination all heifers were relocated to a new paddock and immediately introduced to bulls for a $45 \mathrm{~d}$ breeding season. At time of artificial insemination rectal cervical softness scores were assessed on a scale of 1 to 5 ( $1=$ firm and non-pliable; $5=$ soft and pliable).

Heifers BW was initially measured in November and then consecutive monthly 12 h-shrunk BW from January to the end of the supplementation period in April. At the January and April weigh periods, body condition scores were assessed on a scale of 1 to 9 ( $1=$ emaciated to $9=$ extremely obese) for each heifer by two trained technicians using visual assessment and vertebral palpation techniques [24]. Hip height measurements were obtained once heifers had entered the scale by extracting the tape measure mounted to the top of the scale down to the tail head of the heifer. That distance was subtracted from the overall height from a point stationary on the scale floor. Serum samples were also obtained on monthly weigh days from January through April to evaluate metabolic status and responses due to supplementation strategy. Monthly serum samples were composited for insulin, glucose and NEFA analysis to evaluate overall nutritional status of heifers receiving each supplementary treatment. Commercial kits were purchased to measure serum metabolite concentrations, which included the following: serum urea nitrogen (SUN; Sigma Diagnostics, St. Louis, MO., Cat. No. 66-20, endpoint); glucose (Sigma Diagnostics, St. Louis, MO., Cat. No. 315-100, endpoint); non-esterified fatty acids (NEFA; Wako Chemicals USA, Inc., Richmond, VA, Cat. No. 994-75409, endpoint). Insulin was measured using a commercially available reagents for radioimmunoassay (Diagnostic Products Inc. Los Angeles, CA) as outlined by Reimers et al., [25] with an interassay coefficient of variation of 9.5\% with $100 \%$ recovery.

To determine fecal output chromium sesquioxide slow release boluses (Captec (NZ) LTD., Auckland, New Zealand) were administered to four animals per pasture and two fecal grab samples were obtained 9 and 16 days following administration of the boluses. Fecal samples were dried, ground through a Wiley mill using a $2 \mathrm{~mm}$ screen, prepared, and analyzed for chromium [26].

\subsection{Statistical Analysis}

Data were analyzed as a randomized block design. The Mixed procedure of SAS (SAS Inst. Inc., Cary, NC) was used to analyze the mixed model with pasture as the experimental unit using pasture in the Random statement. Categorical data (i.e., progesterone and pregnancy rate were analyzed using the CATMOD procedure of SAS (SAS Inst. Inc., Cary, NC). Single degree of freedom contrasts tested the effects of protein supplements LRUP + HRUP vs. protein and energy supplement LRUP+E and between protein supplements LRUP vs. HRUP.

\section{Results and Discussion}

Body condition scores were not different among heifers at on test (November), off test (April), and time of pregnancy diagnosis (September: $P \geq 0.65$; Table 3 ). Hip heights were similar $(P \geq 0.09$ ) for all supplemented heifers throughout the study. Initial BW was greater $(P<0.01)$ for LRUP and HRUP heifers than LRUP + E heifers, which was expected due to the experimental design. Similarly, at the end of the developmental period and at time of pregnancy diagnosis, BW remained greater $(P<0.01)$ for LRUP and HRUP supplemented heifer compared to LRUP + E supplemented heifers. Although LRUP + E supplemented heifers were still lighter, LRUP + E heifers were within $8 \mathrm{~kg}$ of the HRUP supplemented heifers and approximately $20 \mathrm{~kg}$ lighter than LRUP heifers prior to breeding.

Heifer BW gains were greater for LRUP supplemented heifers compared to HRUP supplemented heifers from $\mathrm{d} 0$ (November) to $\mathrm{d} 125(P=0.03)$ and the LRUP + E group had similar gains as the LRUP and HRUP groups $(P=0.50)$. However from d 125 to d 159 LRUP + E supplemented heifers had greater gains than LRUP or HRUP supplemented heifers $(P<0.01$; Table 3). Sunvold et al., [27] found that feeding wheat middlings with $20 \%$ CP to cattle consuming dormant range improved dry matter intake (DMI), DM digestibility, and NDF digestibility, indicating additional energy from low starch and greater fiber feedstuffs improved protein utilization of dormant forages. 
Table 3. Body conditions score, hip heights, weights, and average daily gain (ADG; kg/d) for supplemented heifers receiving different concentrations of ruminally undegradable protein with or without additional energy while grazing dormant range forage.

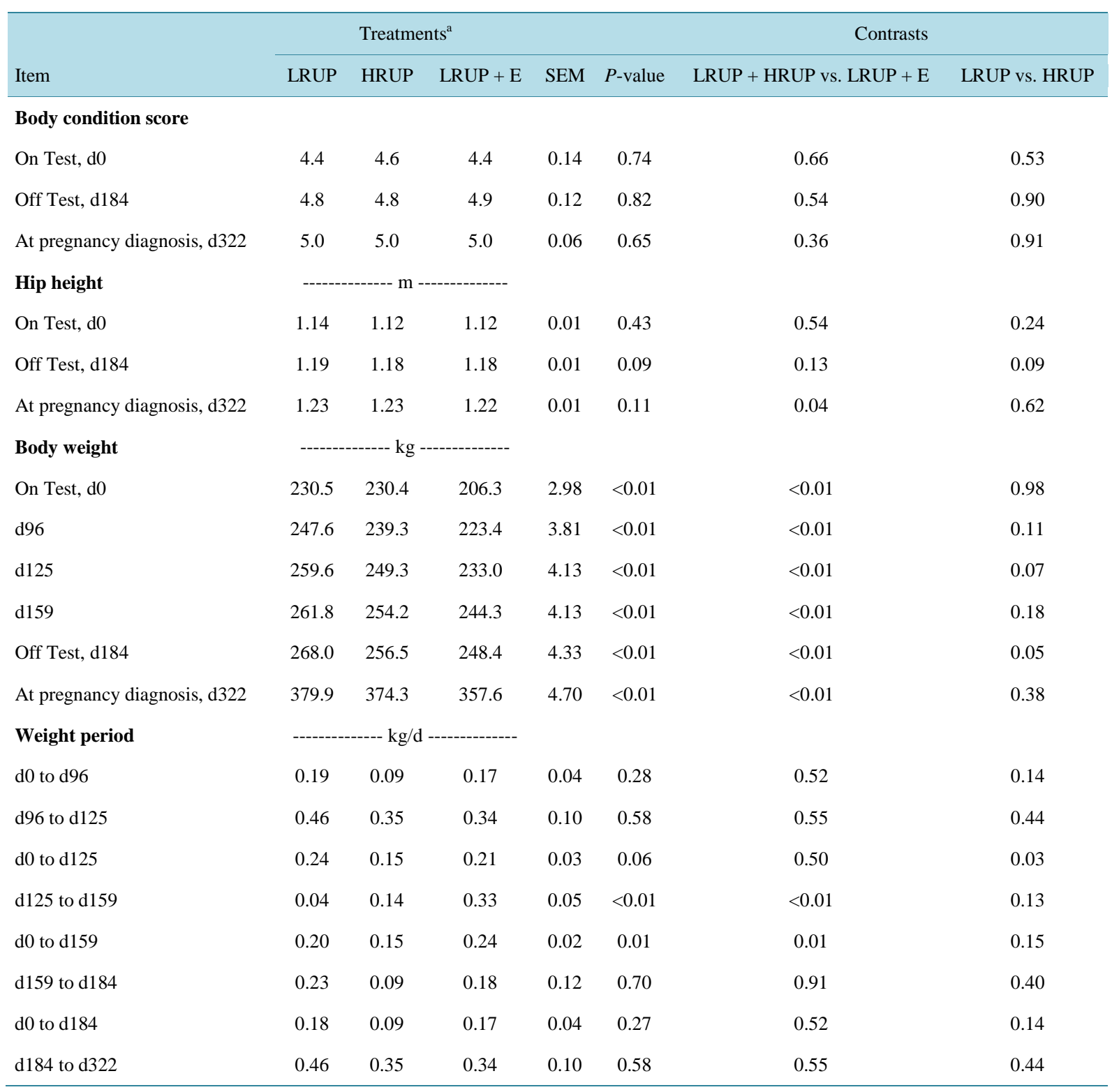

${ }^{\mathrm{a}}$ Least square means \pm standard errors.

Concentrations of SUN on d 96 were greater for the HRUP and LRUP + E $(P=0.01)$ supplemented heifers compared to those fed LRUP (Table 4). On d 159 SUN concentrations were greater $(P<0.01)$ for LRUP + E supplemented heifers compared to LRUP and HRUP supplemented heifers. However, on d 125 and d 184, all heifers had similar $(P>0.54)$ SUN concentrations. Furthermore, SUN concentrations for all heifers were elevated compared to optimal SUN concentrations of 10 to $12 \mathrm{mg} / 100 \mathrm{~mL}$ [28] [29] and may indicate that dietary $\mathrm{CP}$ was fed in excess, leading to an over accumulation of peripheral $\mathrm{N}$ in circulation making it impossible (with SUN as the indicator) to detect potential utilization efficiency differences due to protein type.

Serum insulin concentration tended to differ among supplement treatments $(P=0.08)$; with LRUP $+\mathrm{E}$ fed heifers having a 48\% lower circulating insulin concentrations compared to LRUP and HRUP supplemented heifers $(P=0.05 ; 0.60,0.81$ and $0.34 \pm 0.16 \mathrm{ng} / \mathrm{mL}$, for LRUP, HRUP, and LRUP $+\mathrm{E}$, respectively). This is in contrast to findings where propionate was infused via the jugular vein [30] where insulin concentrations in- 
creased significantly following propionate infusion. These data may indicate that frequent dosing of propionic acid into the rumen may increase sensitivity to insulin by altering the acetate to propionate ratio and supplying more readily available glucogenic precursors for gluconeogenesis in the liver. Serum glucose concentrations tended to differ $(P=0.07)$ with HRUP supplemented heifers having the greatest concentration of glucose $(80.19$, 89.56, and $78.43 \pm 4.04 \mathrm{mg} / \mathrm{dl}$ for LRUP, HRUP, and LRUP + E, respectively). Reference [13] observed lower insulin concentrations in heifers receiving supplements containing propionic acid or monensin at 125, 130, and $140 \mathrm{~d}$ of supplementation compared to heifers receiving a 50\% RUP supplement with similar glucose concentrations. In the present study, we observed similar finding with LRUP + E (i.e. additional propionate salt) supplemented heifers having $48 \%$ less insulin and a tendency to have lower glucose concentrations compared to LRUP and HRUP supplemented heifers. Our findings are comparable to those previously reported by Lalman et al., [13] an indication of enhanced insulin sensitivity in response to supplementary propionate.

Fecal output (OM basis) was similar $(P=0.90)$ for all supplemented heifers $(3.70,3.69$, and $3.26 \pm 0.51 \mathrm{~kg} / \mathrm{d}$ for LRUP, HRUP, and LRUP + E treated heifers, respectively). This data indicates that supplementation strategies utilized in this experiment may have influenced DMI or digestibility of dormant forage similarly.

Reference [14] indicates that prepuberal gain can be manipulated into phases as long as similar target BW is reached which should allow heifers to exhibit puberty prior to breeding. Our results demonstrated that lightweight heifers receiving similar concentrations of CP along with additional energy could achieve a critical BW before puberty. The LRUP $+\mathrm{E}$ treated heifers had a greater $(P=0.04)$ percentage of heifers showing elevated progesterone $\left(\mathrm{P}_{4}\right)$ concentrations $(>1 \mathrm{ng} / \mathrm{ml})$ at the end of the developmental period compared to the LRUP and HRUP treated heifers (Table 5). At time of AI, there were no differences $(P=0.13)$ in cervical scores. Pregnancy rates after a $45 \mathrm{~d}$ breeding period were similar $(P=0.40)$ for all heifers, indicating that protein supplement strategies supported equivalent reproductive competence. In addition, lighter weight LRUP + E fed heifers were nutritionally managed to achieve comparable reproductive success as the initially heavier heifers (Table 3).

Table 4. Serum urea nitrogen concentrations $(\mathrm{mg} / 100 \mathrm{~mL})$ for range heifers throughout the development period supplemented with LRUP, HRUP, and LRUP + E.

\begin{tabular}{|c|c|c|c|c|c|c|c|}
\hline \multirow{2}{*}{ Item } & \multicolumn{3}{|c|}{ Treatments $^{\mathrm{a}}$} & \multirow[b]{2}{*}{ SEM } & \multirow{2}{*}{$P$-value } & \multicolumn{2}{|l|}{ Contrast } \\
\hline & LRUP & HRUP & LRUP+E & & & LRUP + HRUP vs. LRUP + E & LRUP vs. HRUP \\
\hline \multicolumn{8}{|c|}{ Sampling, d } \\
\hline 96 & 15.0 & 17.2 & 18.0 & 0.70 & 0.01 & 0.02 & 0.03 \\
\hline 125 & 19.4 & 20.3 & 21.0 & 1.03 & 0.54 & 0.35 & 0.55 \\
\hline 159 & 12.8 & 12.6 & 15.9 & 0.92 & 0.02 & $<0.01$ & 0.93 \\
\hline 184 & 15.5 & 15.0 & 14.9 & 1.11 & 0.91 & 0.80 & 0.73 \\
\hline
\end{tabular}

${ }^{\mathrm{a}}$ Least square means.

Table 5. Percent of heifers with a progesterone concentration greater than $1 \mathrm{ng} / \mathrm{ml}$ prior to breeding, cervical score (scale 1 to 5 ; 1 = firm and non-pliable; 5 = soft and pliable) given at time of artificial insemination, pregnancy percentage (determined by rectal palpation) on d 322 of study, and average calving date for heifers supplemented with LRUP, HRUP, and LRUP + E.

\begin{tabular}{|c|c|c|c|c|c|c|}
\hline \multirow{2}{*}{ Item } & \multicolumn{3}{|c|}{ Treatments $^{\mathrm{a}}$} & \multirow{2}{*}{$P$-value } & \multicolumn{2}{|l|}{ Contrast } \\
\hline & LRUP & HRUP & LRUP + E & & LRUP + HRUP vs. LRUP + E & LRUP vs. HRUP \\
\hline Progesterone, \% & 29 & 30 & 57 & 0.04 & & \\
\hline Cervical score & 1.5 & 1.7 & 1.9 & 0.13 & 0.12 & 0.16 \\
\hline Pregnancy, \% & 74 & 81 & 65 & 0.40 & & \\
\hline \multicolumn{7}{|l|}{ Average } \\
\hline Calving date following year & $2-24-00$ & $2-25-00$ & $2-21-00$ & 0.30 & & \\
\hline
\end{tabular}

${ }^{\mathrm{a}}$ Least square means. 
Calving dates did not differ the subsequent year $(P=0.30)$, demonstrating that light BW heifers conceived in the same time period as heavier BW heifers.

\section{Conclusion}

In Conclusion, additional quantities of supplement (i.e., energy) provided to the lightweight heifers improved ending body weights. Although, the light BW heifers were $26 \mathrm{~kg}$ lighter at the initiation of the study, LRUP + E supplemented heifers were within 20 and $8 \mathrm{~kg}$ of LRUP and HRUP supplemented heifers, respectively, at the termination of the study. This study indicated that altering RDP to RUP within the amount of protein provided did not change body weight or reproductive performance. Serum urea nitrogen concentrations indicate that supplemental protein may have been fed in excess of requirements and therefore, differences in protein use efficiency would not be expected. However, feeding more supplemental energy (i.e., propionate salt, ground milo and corn) allowed lightweight heifers to become more insulin sensitive, which may have partially allowed for a greater rate of gain than their counterparts while achieving comparable reproductive success.

\section{Acknowledgements}

The authors gratefully acknowledge Drs. Scott Kronberg and Travis Mulliniks for a thorough review of the manuscript prior to submission and to New Mexico Agricultural Experiment Station, Kemin Industries, Inc. Des Moines, IA 50301, and USDA-ARS for their financial support in this project. R. C. W., D. E. H., and M. K. P. designed research; R. C. W, J. E. S., and K. K. K. conducted research; R. C. W. analyzed data, wrote the paper and had primary responsibility for final content. All authors read and approved the final manuscript.

United States Department of Agriculture, Agricultural Research Service, Northern Plains Area, is an equal opportunity/affirmative action employer. All agency services are available without discrimination. This research was conducted under a cooperative agreement between USDA-ARS and the Montana Agric. Exp. Stn. Mention of a proprietary product does not constitute a guarantee or warranty of the product by USDA, Montana Agric. Exp. Stn., or the authors and does not imply its approval to the exclusion of other products that also may be suitable.

\section{Author Disclosures}

R. C. Waterman, J. E. Sawyer, K. K. Kane, D. E. Hawkins, and M. K. Petersen have no financial interest in the outcome of this study.

\section{References}

[1] Wallace, J.D. and Parker, E.E. (1992) Range Supplements-What We Have Learned. Livestock Research Briefs \& Cattle Growers Short Courses, 20-27.

[2] NRC (2000) Nutrient Requirements of Beef Cattle. 7th Edition, National Academies Press, Washington DC.

[3] Krysl, L.J., et al. (1987) Cattle Nutrition on Blue Grama Rangeland in New Mexico. New Mexico Agricultural Experiment Station Bulletin, 727, 1-35.

[4] Cochran, R.C. (1995) Developing Optimal Supplementation Programs for Range Livestock. Kansas State University Field Day. 50 Years of Range Research Revisited. Cooperative Extension Service, Kansas State University, Manhattan, 58-72.

[5] Clanton, D.C. (1982) Crude Protein System in Range Supplements. In: Owens, F.N., Ed., Symposium of Protein Requirements for Cattle, Stillwater, 228-234.

[6] Leng, R.A., Economides, S. and Ball, F.M. (1978) The Effects on Growth of Supplying Glucose Continuously into the Duodenum of Lambs on Low-Protein Diets. Proceedings of Australian Society of Animal Production, 12, 134.

[7] Lesmeister, J.L., Burfening, P.J. and Blackwell, R.L. (1973) Date of First Calving in Beef Cows and Subsequent Calf Production. Journal of Animal Science, 36, 1-6.

[8] Short, R.E. and Bellows, R.A. (1971) Relationships among Weight Gains, Age at Puberty and Reproductive Performance in Heifers. Journal of Animal Science, 32, 127-131.

[9] Wiltbank, J.N., et al. (1966) Effects of Heterosis on Age and Weight at Puberty in Beef Heifers. Journal of Animal Science, 25, 744-751.

[10] McCartor, M.M., Randel, R.D. and Carroll, L.H. (1979) Dietary Alteration of Ruminal Fermentation on Efficiency of 
Growth and Onset of Puberty in Brangus Heifers. Journal of Animal Science, 48, 488-494.

[11] Moseley, W.M., et al. (1982) Relationship of Growth and Puberty in Beef Heifers Fed Monensin. Journal of Animal Science, 55, 357-362.

[12] Floyd, C.R., et al. (1995) Effects of Monensin and 4-Plex on Growth and Puberty of Beef Heifers. Oklahoma State University Animal Science Research Report, Oklahoma State University, Stillwater, 943, 75-80.

[13] Lalman, D.L., et al. (1993) The Effects of Ruminally Undegradable Protein, Propionic Acid, and Monensin on Puberty and Pregnancy in Beef Heifers. Journal of Animal Science, 71, 2843-2852.

[14] Clanton, D.C., Jones, L.E. and England, M.E. (1983) Effect of Rate and Time of Gain after Weaning on the Development of Replacement Beef Heifers. Journal of Animal Science, 56, 280-285.

[15] Wessels, R.H., et al. (1996) Lasalocid Effects on Ruminal Degradation of Protein and Postruminal Supply of Amino Acids in Holstein Steers. Journal of Dairy Science, 79, 1802-1808. http://dx.doi.org/10.3168/jds.S0022-0302(96)76548-7

[16] Moseley, W.M., McCartor, M.M. and Randel, R.D. (1977) Effects of Monensin on Growth and Reproductive Performance of Beef Heifers. Journal of Animal Science, 45, 961-968.

[17] Jenkins, T.C. and Thonney, M.L. (1988) Effect of Propionate Level in a Volatile Fatty Acid Salt Mixture Fed to Lambs on Weight Gain, Body Composition and Plasma Metabolites. Journal of Animal Science, 66, 1028-1035.

[18] Forbes, A. (1999) Taxonomy of the Flora of the Corona Range and Livestock Research Center. M.S. Thesis, New Mexico State University, Las Cruces.

[19] Knox, L.A. (1998) The Responses of Beef Cattle Grazing Native Rangeland to Management Fecisions. M.S. Thesis, New Mexico State University, Las Cruces.

[20] Lesperance, A.L., Bohman, V.R. and Marble, D.W. (1960) Development of Techniques for Evaluating Grazed Forage. Journal of Dairy Science, 43, 682-689. http://dx.doi.org/10.3168/jds.S0022-0302(60)90219-8

[21] AOAC (1990) Official Methods of Analysis. 15th Edition, Association of Official Analysis Chemists, Arlington.

[22] Goering, H.K. and Van Soest, P.J. (1970) Forage Fiber Analyses (Apparatus, Reagents, Procedures, and Some Applications). Agriculture. Handbook No. 379, USDA-ARS, Washington DC.

[23] Schneider, F.A. and Hallford, D.M. (1996) Use of a Rapid Progesterone Radioimmunoassay to Predict Pregnancy and Fetal Numbers in Ewes. Sheep and Goat Research, 12, 33-38.

[24] Herd, D.H. and Sprott, L.R. (1986) Body Condition, Nutrition and Reproduction of Beef Cows. Texas Agricultural Extenstion Service, B-1526, 1-11.

[25] Reimers, T.J., et al. (1982) Validation of a Rapid Solid-Phase Radioimmunoassay for Canine, Bovine, and Equine Insulin. American Journal Veterinary Research, 43, 1274-1278.

[26] Williams, C.H., David, D.J. and Iismaa, O. (1962) The Determination of Chromic Oxide in Feces Samples by Atomic Absorption Spectrophotometry. Journal of Agriculture Science, 59, 381-385. http://dx.doi.org/10.1017/S002185960001546X

[27] Sunvold, G.D., Cochran, R.C. and Vanzant, E.S. (1991) Evaluation of Wheat Middlings as a Supplement for Beef Cattle Consuming Dormant Bluestem-Range Forage. Journal of Animal Science, 69, 3044-3054.

[28] Hammond, A.C., Kunkle, W.E., Bates, D.B. and Sollenberger, L.E. (1993) Use of Blood Urea Nitrogen Concentration to Predict Response to Protein or Energy Supplementation in Grazing Cattle. Proceedings of the 17th International Grassland Congress, Rockhampton, 1989-1991.

[29] Stateler, D.A., Kunkle, W.E. and Hammond, A.C. (1995) Effect of Protein Level and Source in Molasses Slurries on the Performance of Growing Cattle Fed Hay during Winter. Journal of Animal Science, 73, 3078-3084.

[30] Peters, J.P. and Elliot, J.M. (1984) Endocrine Changes with Infusion of Propionate in the Dairy Cow. Journal of Dairy Science, 67, 2455-2459. http://dx.doi.org/10.3168/jds.S0022-0302(84)81596-9 
Scientific Research Publishing (SCIRP) is one of the largest Open Access journal publishers. It is currently publishing more than 200 open access, online, peer-reviewed journals covering a wide range of academic disciplines. SCIRP serves the worldwide academic communities and contributes to the progress and application of science with its publication.

Other selected journals from SCIRP are listed as below. Submit your manuscript to us via either submit@scirp.org or Online Submission Portal.
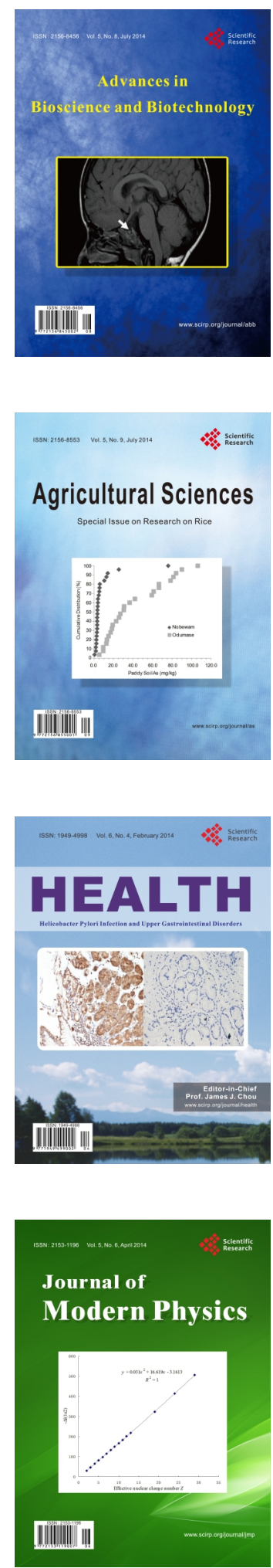
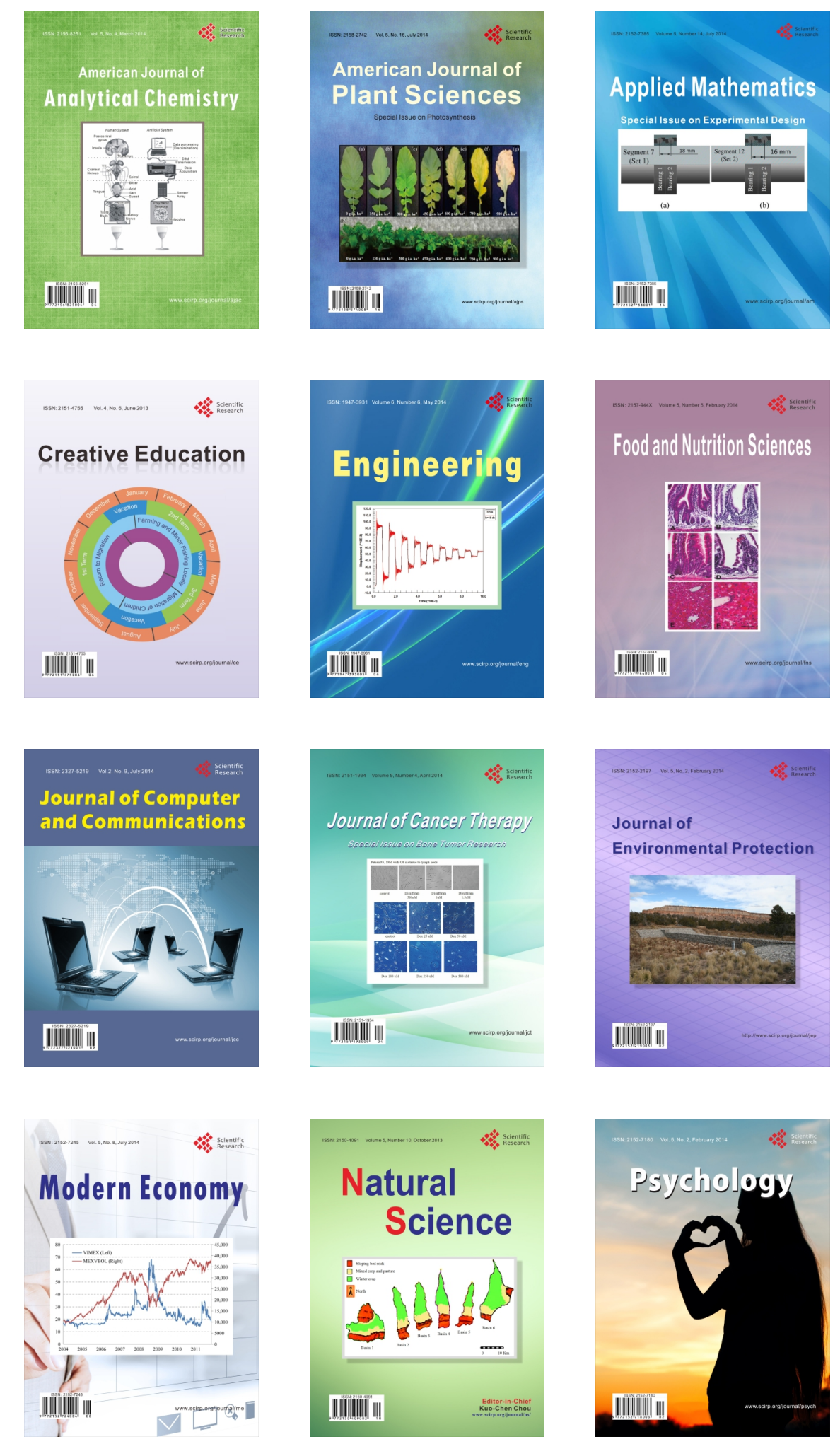